\title{
Innovative post-neoliberal policy as a way out of crisis? Another reflection on the case of urban decline in Detroit
}

\author{
Nebojša Čamprag* (10)
}

\begin{abstract}
Introduction: Many scholars have discussed urban decline, and one of the emerging discourses has called for redefining the crisis as an opportunity to establish new urban governance models. This paper evaluates the outcomes of such innovative approaches to managing urban decline by identifying its major implementation challenges, effects and outcomes, and pointing out long-term development perspectives.

Case description: The focus was on Detroit, the 'greatest failure' among the troubled large cities in the US, whose municipal government, policy makers and elites have invested a great deal of effort to stem the city's rapid decline.

Discussion and evaluation: Of particular interest was the period since 2013 when the city government declared bankruptcy. An innovative strategy based on stabilisation, recovery, and irreversible degrowth was then embraced. The research method to investigate the efficiency of its implementation is centered on analysis of the secondary literature, strategies and official documents designed by the local government and private foundations in Detroit, as well as of supporting news reports.

Conclusions: In conclusion, besides the importance of redefining approaches to urban policy-making in declining cities, the study illustrated the necessity of developing equally innovative alternative ways for their successful implementation.
\end{abstract}

Keywords: Declining cities, Urban governance, Strategic response, Urban renewal, Detroit

\section{Background}

Neoliberal ideology, based on the belief that "open, competitive, and unregulated markets, liberated from all forms of state interference, represent the optimal mechanism for economic development" (Brenner and Theodore 2002, p 349), influenced urban governance models in the cities of the Global North for decades. However, blinded by the aim of achieving capitalist growth, institutional path dependency failed at providing a coherent and sustainable basis for urban development in the postindustrial society (Bontje 2004; Häußermann and Siebel 1988; Liebmann and Kuder 2012). The consequences of reliance on one-dimensional development model showed

*Correspondence: camprag@stadt.tu-darmstadt.de Faculty of Architecture (Mundus Urbano), Technical University of Darmstadt, El-Lissitzky-Straße 1, 64287 Darmstadt, Germany the most visible effects on the example of urban decline among the former industrial giants of the so-called Rust Belt in the US. Although a significant body of literature has discussed the phenomenon of urban decline, an emerging discourse has called for redefining the crisis as an opportunity to refine neoliberal local policy solutions that feature innovation, dynamism, and collaboration (Katz and Bradley 2013; Oosterlynck and González 2013; Tabb 2015). The emerging 'post-neoliberal' alternatives thus advocated for the approaches towards "more just, democratic, ecological city-regions (...) to be taken more seriously" (Oosterlynck and González 2013, p 1076). This finally implied the focus on growth objectives turning towards alternative solutions, in which adopting some aspects of degrowth in the short-term could lead to prosperity in the long run (Schindler 2016). 
As best-known declining city in the world, Detroit began to deteriorate after the crisis in its main industry: the car-manufacturing sector. Detroit's policy makers struggled to find new approaches to deal with troubled heritage of its industrial past and respond to new conditions. On the one hand, strategic approaches needed to take control over further decline, but on the other hand to propose innovative solutions for giving rise to progressive long-term urban politics. The focus of this study is thus on the challenges and opportunities in responding to urban decline, theorised in terms of innovative strategic frameworks to oppose decline that propelled interaction between the state, private sector and civil society. More specifically, the study builds upon the dependency of urban development policies on industrial and commercial paths of development that created "the context for a relatively slow reaction to the economic and social conditions of decline" (Liebmann and Kuder 2012, pp 1169-1170), and upon the argument to use the crisis to test new urban governance models (Oosterlynck and González 2013). The major research aims are to identify the main challenges to the implementation of innovative responses to urban decline, evaluate their effects and outcomes, and discuss their long-term development perspectives. This was done based on a review of the secondary literature to reflect and connect with previous research. Analysis of the selected strategies and official documents designed by the local government and private foundations in Detroit provided a deeper insight into development directives of interest. Finally, analysis of the news reports for the period since 2000 offered a valuable overview of outcomes and public reactions to strategies and initiatives relevant for the research objectives.

The first section of the paper introduces the theoretical background on the shift from growth paradigm to redefining urban shrinkage as a source for new urban governance models, and summarises characteristics of decline in the context of post-industrial cities of the Rust Belt. The second section presents the case study and provides an overview of decline and strategic responses. The third section reflects on the insights gained through the case study analysis regarding strategic approaches to oppose crisis through innovative urban governance models. The paper concludes with an assessment of the case study in the light of effective strategic responses to urban shrinkage in urban development politics.

\section{Urban decline and the context of post-industrial US cities}

Urban decline has been acknowledged as a global and multidimensional phenomenon, and as a long-term, structural component of urban development (MartinezFernandez et al. 2012). It did not attract international attention until 2000 because the dominant paradigm among planners and policy makers was oriented exclusively to growth (Logan and Molotch 1987; Oswalt and Rieniets 2006). However, with population decrease and urban decline being placed on the agenda of many cities, planners and policy makers finally turned their attention away from growth.

In Germany, the debate on shrinking cities (schrumpfende Städte) began in 1990. Shortly thereafter it was described in the US in terms such as urban decline, urban decay or simply depopulation (Pallapst et al. 2011). Urban researchers had to find comprehensive explanations for the variety of manifestations and conditions of decline, in addition to investigating its trajectories, conflicting interests, and hardly predictable trends (Martinez-Fernandez et al. 2012; Steinführer et al. 2010). There was a general lack of "(...) systematic empirical analysis of the crisis as a 'laboratory' for urban governance models" (Oosterlynck and González 2013, p 1076). The 2008 financial crisis highlighted constant restructuring of urban neoliberalisation, making implications for urban governance and planning practice towards finding alternatives in 'smart decline' and recognising potential in decline. As neoliberal urban restructuring processes, crises could be used to "effectively produce new, post-neoliberal urban governance rationalities" (ibid: 1076) to create more just, democratic and ecological cities. Thus, a better knowledge of urban politics in crisis could reveal the hidden potential of urban decline and to use it to restore prosperity to declining cities.

Considering the very close links between the western industrial model and urban development, the transformation and decline of industrial modes of production had far-reaching consequences for the former industrial cities of the US (Short 1996). Although the rapidly rising loss of jobs and residents that commenced in the decades after the World War II significantly slowed down during the 1980s and the 1990s, former industrial centres like Youngstown, Erie, Flint, Detroit, Bridgeport, Camden and Rochester continued to shrink (Beauregard 2007). While it is still largely a matter of debate why these cities didn't manage to break off from the long period of decline, planning practice in the US remained focused on the management of urban growth. The rare cases of tackling redevelopment were usually performed at the local level and in a rather fragmented way, often without any strategic support coming from the higher levels of government (Pallagst 2009).

Contrary to the less adaptable planning practice, the research on urban shrinkage in the US offers a broader understanding of its many accompanying phenomena, such as sub-urbanisation, growth and concentration of urban poverty, racial segregation, and immigration 


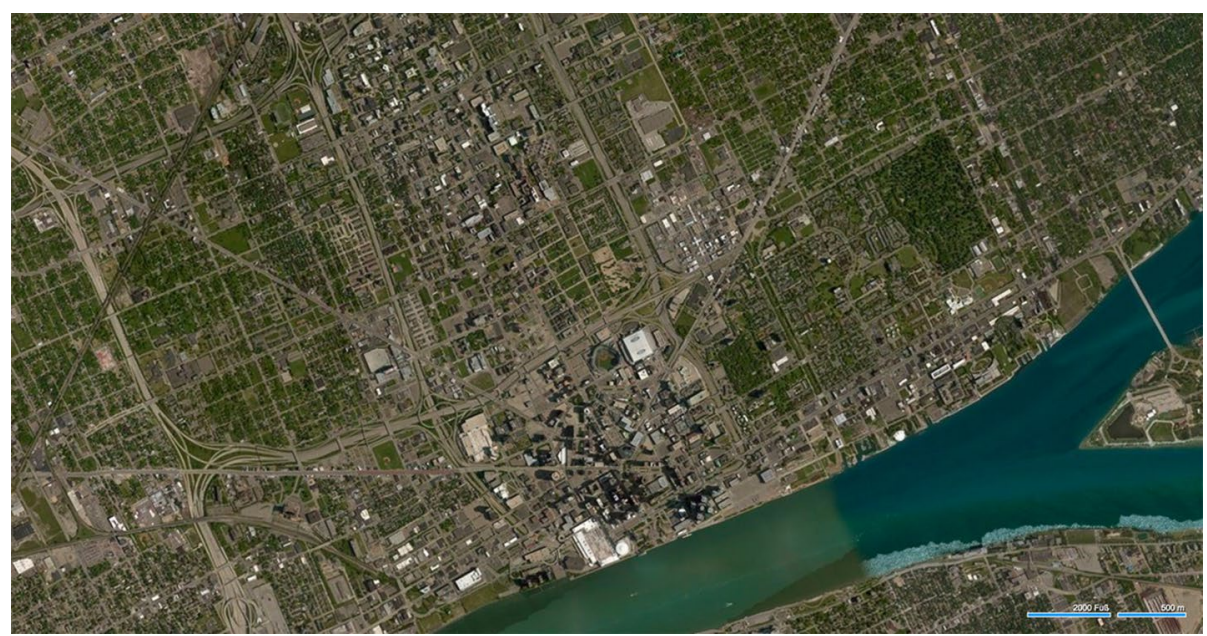

Fig. 1 Detroit's physical urban structure (source: https://www.bing.com/maps @ 2018 Microsoft)

(Audirac 2009; Bentley et al. 2016; Martinez-Fernandez et al. 2012). Based on the outcomes of this research, it is possible to determine some major characteristics of decline in the cities of the Rust Belt. Firstly, scholars agree that long-term post-industrial transformation is the main driver of urban decline. Secondly, the process mostly affected urban cores, while suburban regions continued to grow, due to a process rooted in the long history of spatial segregation at the intersection of race and class (Bentley et al. 2016). Thirdly, the public sector seemed to be less powerful than in the cities of the Western Europe, and was thus more dominated by growth regimes (Audirac 2009). Finally, there was evidence of the link between decline in the cities of the Rust Belt and the lack of competition in labour and output markets, as a consequence of the behaviour of powerful labour unions and a small set of oligopolists who stifled competition (Alder et al. 2014). This indicated that institutional path dependency developed in times of prosperity, and became the main impediment to institutional change and adaptation in times of crisis.

This paper discusses the decline of Detroit in light of its post-industrial recovery. This case study is of particular interest as it could be considered an extreme example of reliance upon the manufactory mode of production, followed by the demise of the industrial sector. In addition, what is most relevant for the objectives of this paper is the interplay between institutional path dependency, developed in times of prosperity, and the need for innovative responses to crisis. Finally, strategic response to decline, based on innovation and a break with the past, created particular challenges in the interaction among the state, the private sector and civil society, thus making effects on the implementation results. The following section introduces the topic of urban decline in Detroit, and an overview of early strategic approaches to decline.

\section{Background of the crisis in Detroit and analysis of the following responses to decline}

Detroit became the centre of global automobile production itself after Ford Motor Company made automobiles affordable to wider masses. The city soon became an industrial powerhouse for the Big Three: Ford Motors, General Motors and the Chrysler Corporation. By 1920 Detroit had one million inhabitants, and four decades after, the city was the fourth-largest in the US with nearly 1.8 million residents. However, serious problems in automobile production, racial tension and urban unrest coincided with the first job losses and population decline in the 1960s (McIntyre Hall and Hall 1993; Owens and Rossi-Hansberg 2017). The downfall of the city was linked to decline of the General Motors and its bankruptcy in 2008, the largest corporate bankruptcy in American history. 5 years later, Detroit became the largest city in the US to declare bankruptcy (Neill 2015).

A 2013 study of indicators associated with quality of life, such as poverty, unemployment, crime, health, housing and education designated Detroit as America's Most Miserable City (Badenhausen 2013). The problems ranged from deindustrialisation and disinvestment to social problems-such as a growing population of the vulnerable poor, identity crisis, brain drain, and white flight. More than $50 \%$ of the manufacturing jobs had been eliminated. Skyrocketing home abandonment, plummeting tax revenues, and escalating taxes reduced population by almost $25 \%$. The problems of poverty and segregation were exacerbated after the 2007 subprime mortgage crisis, in which an estimated 750,000 people in the US lost 
their homes; 107,500 in September 2007 alone (Watson and Moore 2008). Dramatic fall of population reaching $63 \%$ in only six decades resulting from the 'white flight' also listed Detroit among the most segregated cities in America, with $82.7 \%$ of African American population according to the 2010 census (The U.S. Census Bureau 2016).

Decades of rapid decline threw Detroit's physical urban structure into disarray, and resulted with centrally located business district, closely surrounded by largely vacant neighbourhoods (Fig. 1). In 2013 there were approximately 78,000 abandoned homes, with one-third of the urban territory either derelict or vacant (Snyder 2013). The suburbs were characterised by low land and real estate prices, ${ }^{1}$ with many houses torched or in disrepair. There were no substantial adjustments, either of city's layout, or of its structure, except from demolishment of over 100,000 vacant housing units since the 1980s.

Since its establishment in 1935, the United Automobile Workers Union (UAW) took on a large stake in improving work conditions by lobbying for progressive social and economic legislation. Some of Michigan's politicians blamed this legislation for pushing Detroit out of world auto markets (Tabb 2015). Nevertheless, the most logical explanation of the city's dramatic decline is that local elected officials were not willing to make hard choices for addressing changing circumstances. Some researchers have argued that Detroit was facing urban death as a consequence of a failure of crucial urban functions, including governance and economic opportunities (see Eisinger 2014).

\section{Rise and fall of the initiatives coming from the private sector}

Investment and social climate in Detroit began to change in the 1990s. Until the first attempts for development of a comprehensive strategy for urban rehabilitation, there were some incoherent initiatives from public and private developers and investors, reaching approximately $\$ 12$ billion invested in building projects ${ }^{2}$ (City of Detroit 2000). Also a few federal measures were implemented, mostly to

\footnotetext{
${ }^{1}$ Detroit's real estate market in the meanwhile became an investment craze for the rich Chinese investors, who were looking to buy properties in bulk, but without plans to move to the Detroit area (Florcruz 2013).

${ }^{2}$ A few minor but important infrastructure improvements were made to erase some of the traces of Detroit's chronic devastation and dysfunction, such as refurbishment of city parks, revetments of streets and repair of street lamps. Two new professional ballparks were built, several old movie and vaudeville theatres restored, and the city constructed a half-mile long riverside walk. Three private gambling concerns built their casinos on the edge of the downtown, along with a few new restaurants and several clubs (Eisinger 2003; Tabb 2015).
}

stimulate economic and community development in some of the poorest neighbourhoods. Nevertheless, entrepreneurial development from the private sector quickly took the lead in physical refurbishment; the Kresge Foundation ${ }^{3}$ alone has invested more than $\$ 100$ million in Detroit's transformation, from funding a riverfront promenade and building greenways to backing incentives for entrepreneurs (Dolan 2011).

The General Motors made what appeared to be the most iconic investment after purchasing the riverside Renaissance Centre office complex in 1996 and making the renovated complex for its global headquarters in 2004 (Fig. 2). Businessman Dan Gilbert moved his company, Quicken Loans, to downtown Detroit in 2010 to support its revitalization. Gilbert later purchased millions of square feet in dozens of repurposed buildings in the urban core, and the impact of these initiatives is apparently still on the rise (see Gallagher 2017). However, in contrast to a high number of interventions coming from the private sector in the downtown area, none of them actually considered long-term implications for the city's society and economy. The private sector also didn't consider the growing problem of land vacancies in the urban outskirts that attracted dumping, discouraged new investments, and harmed nearby property values. Even one of the few big investments outside of the downtown area, the software company Compuware that was headquartered in the Detroit suburbs, later moved thousands of its high-tech white-collar employees into the downtown office tower (Laitner 2017). Due to such imbalanced development, also Detroit's Renaissance Centre, once described as the world's largest private development and the symbol of the auto giants' resurgence, was finally criticised in Britain's Guardian as it.

\section{(...) appears to have done essentially nothing to reduce Detroit's loss of industry, investment and appeal (Marshall 2015).}

Although USA Today had praised Gilbert as "Detroit's Savior" (Bomey and Woodyard 2014), the New York Times later complained that some of his massive investments turned Detroit into a "company town" (Creswell 2017). This referred to immense influences in neighbourhood development, in the provision of public services, and a lack of support for civic institutions. The Quicken Loans Company itself has been criticised for being

\footnotetext{
3 The Kresge Foundation is "a $\$ 3.6$ billion private, national foundation that works to expand opportunities in America's cities through grant making and social investing in arts and culture, education, environment, health, human services and community development in Detroit" (The Kresge Foundation 2017).
} 


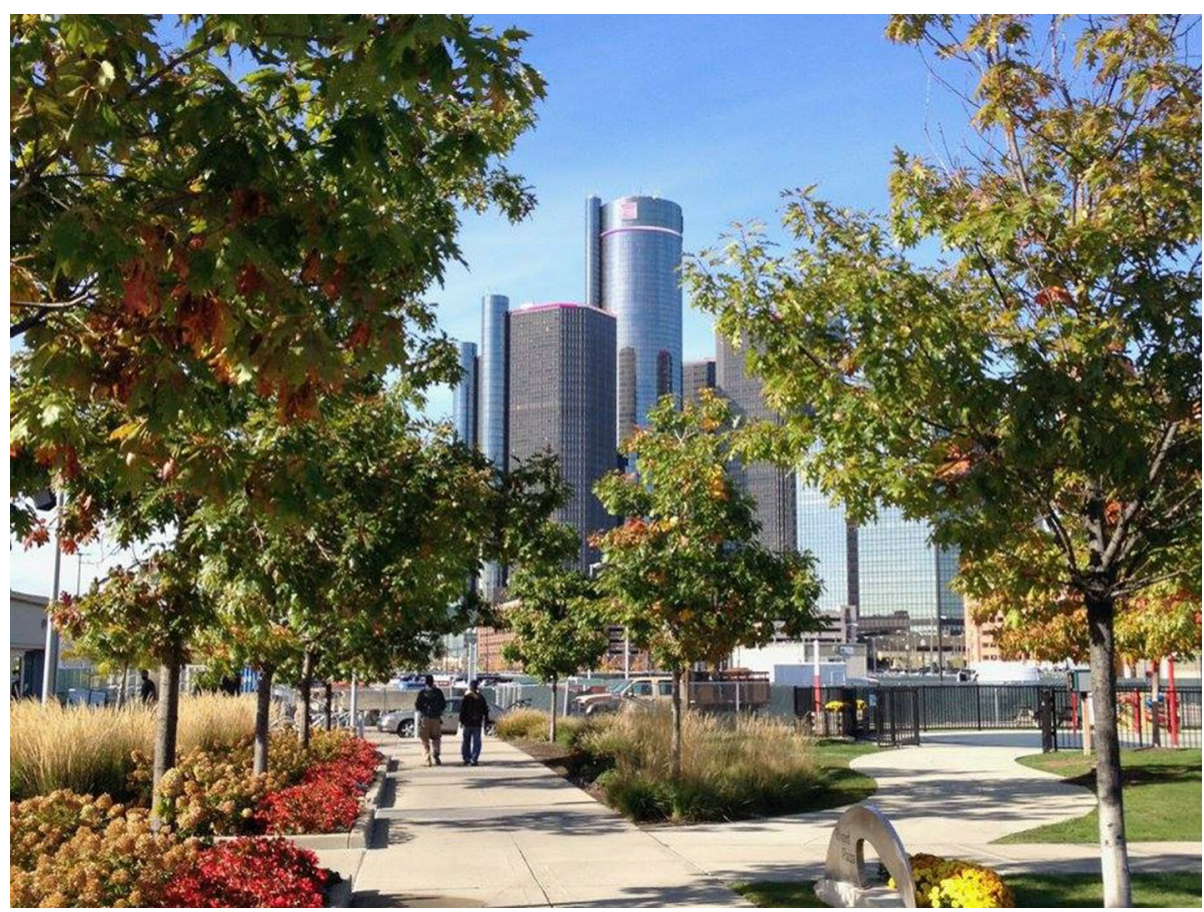

Fig. 2 The Renaissance Centre seen from the riverside walk. Author's photo, 2017

(...) a leader in the nation's shadow-banking system, a network of nonbank financial institutions that has gained significant ground against its more heavily regulated bank counterparts in providing home loans to Americans (Creswell 2017).

Like the interventions from the private sector that struggled to achieve comprehensive responses to urban decline in Detroit, public-sector interventions coming from different quarters of the public sector also failed to gain support and deliver desired outcomes. Mayor Kwame Kilpatrick's attempt to restructure the pension debt fund only made the city more vulnerable as the loan eventually accounted for one-fifth of the city debt (Borney and Gallagher 2013). Another example was the plan of the federal government to redistrict shrinking Michigan cities, aiming at levelling shifting demographics on the vast urban territory with a reduced population (The Huffington Post 2012). Some grassroots leaders in Detroit later called this well-intended initiative a way to create districts that gave an advantage to those in power, while depriving poor and disadvantaged of representation (Oosting 2017). Considering these outcomes, some new urban governance strategies seemed to be necessary. The quest for an strategic framework thus encompassed systematic reforms, along with "the spirit of innovation" in order to make the city "great", as highlighted in the Detroit Future City strategic framework (2012, p 12).

\section{Innovative bottom-up alternative as the new urban governance tool}

The necessity for redefining urban perspectives was announced with comprehensive adaptations of the formerly dominating industrial sector. General Motors repaid its $\$ 50$ billion loan to the federal government and even showed some signs of recovery after it became a smaller, more fuel-efficient, and thus more competitive car manufacturer. The most promising alternative to the industrial sector, however, implied the early attempt to set up some strategies based on the potentials of cultural production. As the image of Detroit as a dying city was extremely hard to reverse, artistic and cultural activity was seen as crucial for community engagement and revitalization. This potential had been seen in the music business, international jazz, electronic music, and country music festivals in which entertainment became a means of job creation. The Kresge Foundation's attempt to identify, document and analyse Detroit's cultural resources, the "Detroit Cultural Mapping Project" of 2011 was the first step in the mobilisation of the city's cultural potential. This report urged Detroit to break with its industrial past, seeing its creative cultural sector as

(...) the 'new economy' of smaller, more nimble entrepreneurial enterprises that carry with them a different kind of economic narrative than the one associated with Detroit's past (Dickinson Blais 2012, p 76). 
The premise of the initiative was much broader, providing a strategy across a wide range of civic activities for stabilization and revitalization, in which

(...) Detroit's renewal will depend on vertical alignment among local, State and federal interests and investments, as well as horizontal alignment based on new coalitions of public, private and non-profit sectors (Dickinson Blais 2012, p 2).

Similar incentives appeared in other modes of cultural production. Michigan Governor Jennifer Granholm encouraged motion picture production through tax breaks for filmmakers. Other notable initiatives from the private sector to support culture-based strategies included successful fund-raising events that assisted the city in keeping its valuable art collection. ${ }^{4}$

The centrepiece of the emerging reliance to innovative alternative was the Detroit Future City Strategic Framework (DFC) in 2013 (City of Detroit 2013). The main objectives of this detailed long-term guide for decisionmaking in Detroit entailed abandoning the industrial past as a prerequisite for development of new ways to increase employment and residential density. Although manufacturing retained an important place in Detroit's development, diversifying the city's economy commenced with supporting alternative economic sectors that had shown success in job creation, such as digital and creative jobs, education and medical employment, employment in new industrial sectors, and local entrepreneurship. In spatial terms, the framework was focused on seven employment districts in which job growth was already occurring. The second objective was to stabilise neighbourhoods, as abandonment was the main threat to the city's sustainable future. This included creation of a diverse range of neighbourhood styles and choices that would appeal to a wide variety of people, and concentrate the population in areas with higher densities. The third objective used the potential for the creative transformation of vacant land and buildings, as the city's greatest but the most challenging asset (Kinkead 2015; Detroit Future City 2012). Other objectives involved reforming the service delivery systems, taking a collective approach to land and buildings in the city, and the participatory implementation of planning elements (DFC Implementation Office 2017).

The DFC strategy could be perceived as a "(...) powerful milestone in the continued rebirth of the City of Detroit” (Reece and Holley 2013, p 9), considering “(...)

\footnotetext{
${ }^{4}$ Initially considered for selling off to cover the debts after the city went bankrupted, the Detroit Institute of Arts raised more than $\$ 800$ million in a fundraising action to keep the collection. The city's cultural heritage was thus 'ransomed' from city ownership and was no longer dependent on financial problems of the municipality.
}

moving the planning process from concept to implementation and reality, creating yet another tremendous opportunity for Detroit" (ibid.). An editorial in the Detroit Free Press even called the plan revolutionary, and urged its immediate implementation (Detroit Free Press 2013). Overall public support for this strategy resulted from the inclusion of local and national experts, from the insights of tens of thousands of citizens (City of Detroit 2014), and from its outstanding, innovative features. The DFC was not only the first strategic framework that advocated for an integrated way of transforming the city and its neighbourhoods, but also the first to accept that Detroit will never again be a city of nearly two million people. In addition, the plan prioritised stabilisation of the city's economy over economic growth, while its longterm future depended on improving the quality of life of its residents. Instead of being quantitatively ambitious, it aimed at building civic capacity through collaboration, information and resources. Finally, its realization involved long- and near-term priorities ${ }^{5}$ that would be adjusted and updated (City of Detroit 2014).

Considering that the core of the DFC strategy was the urge for experimentation, entrepreneurship, and innovation to make Detroit "(...) a global leader in technology and innovation" (City of Detroit 2012, p 31), the important prerequisite for policy makers was to adopt the stance that

\section{(...) doing business as usual is no longer an option for Detroit. The financial recession and foreclosure crisis in 2007 (...) created a heightened sense of urgency and opportunity among Detroiters, and has resulted in this initial work to solidify a public consensus for systematic reform and innovation. (...) Yet the major and most sweeping innovations will take 20 or more years to realize (City of Detroit 2012, p 15).}

The DFC strategy therefore needed to centre on longterm objectives but with flexible, short-term objectives that required incremental implementation. The first phase, lasting until 2020, was geared towards stabilising economy and population; however, the following phase (2020-2030) aimed at preparing residents and business for economic growth. Between 2030 and 2050, the city would regain its status as "one of the most competitive cities in the nation" (Detroit Free Press 2013).

\footnotetext{
5 The priorities for 2014-2015 were to ensure more employment in the city, keep the policy and regulation updated to respond to the circumstances and opportunities, improve system and service performance, stabilise neighbourhoods, and transform vacant land into an innovative open space network. This physical transformation of old, unused industrial facilities and reclaiming vacant land were to become the key for employment growth, particularly in the agriculture and manufacturing sectors.
} 


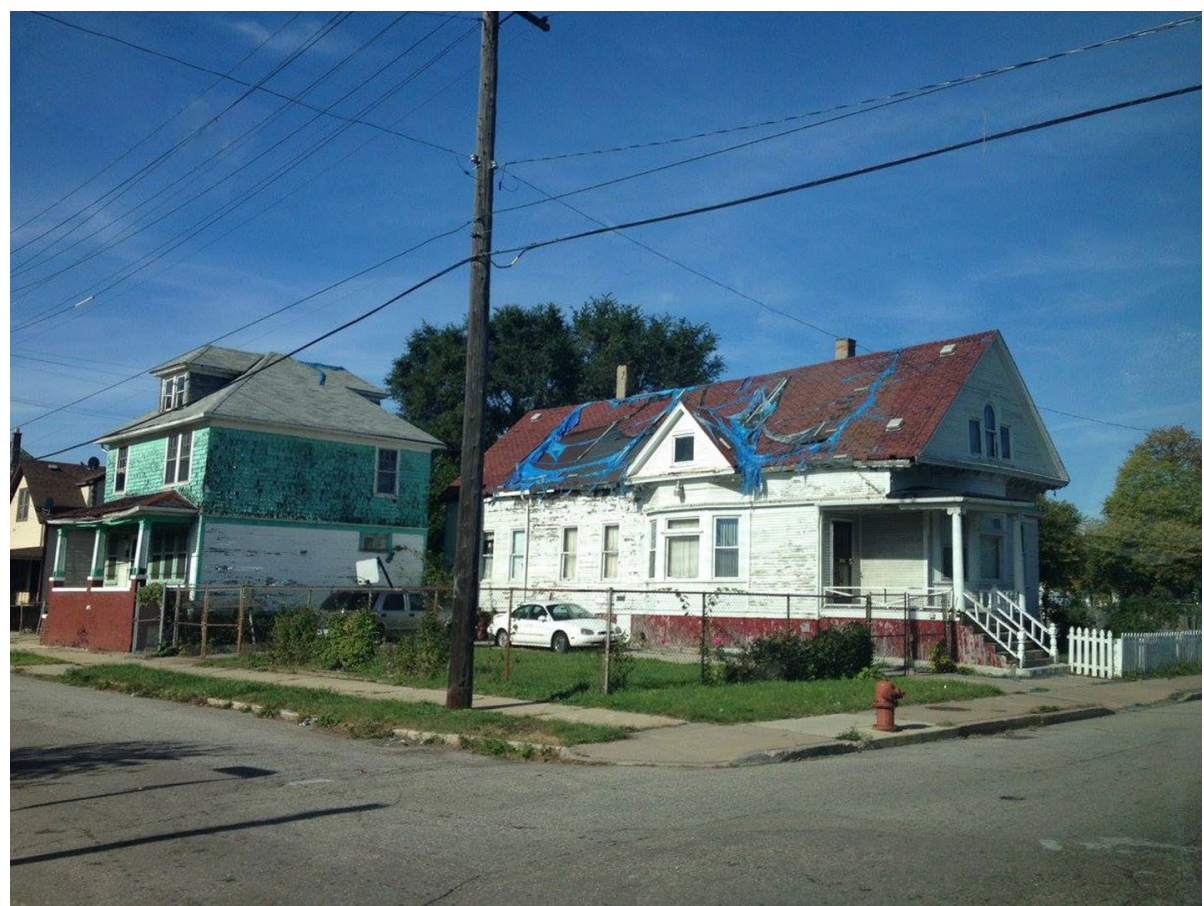

Fig. 3 Declining neighbourhoods in Detroit. Author's photo, 2017

To realise this vision, the Detroit Economic Growth Corporation (DEGC) created the DFC Implementation Office, a non-profit organisation governed by an independent board of directors, and who were prominent members from the public, private and philanthropic sectors. Such opportunity-oriented development and investment, based on robust engagement of citizens and other stakeholders in cultivating innovative action for Detroit's long-awaited transformation, was surely a promising model. The study "Detroit at a Crossroads" from the Kirwan Institute evaluated the dynamics of inequity, opportunity and prosperity in Detroit following the devastating recessions, described these efforts as a model for other cities in the US;

Today, Detroit presents a potential model for the future of urban America, a vision of what can be for cities across our nation, cities that have struggled with a history of segregation and dramatic economic transition. If Detroit is successful, it will serve as a model for revitalization, equity and sustainability for our nation's cities and cities across the globe (Reece and Holley 2013, p 2).

The DFC strategy had its most pronounced effect on property vacancy rates in the city (Fig. 3). The new policy suggested encouragement of investment and home ownership, while local authorities strived to ensure efficient allocation of deserted or empty lots after taking possession of those whose owners had stopped paying property taxes. ${ }^{6}$ The Department of Planning and Development (PDD) managed empty lots through the land bank authority, with the aim of auctioning off the property. With the idea of efficient selling off the land, the responsibility over its maintenance was supposed to be turned into securing revenues. Many private companies and non-profit organisations made significant contributions to the reuse of vacant land in the city, not only for food production, but also as places to learn, socialize, and spend quality time. It was estimated that until 2015 there were around 1400 active urban gardens and farms in Detroit (Held 2015), some of them showing extraordinary results. As an illustration, the non-profit Michigan Urban Farming Initiative promoted organic and sustainable agriculture, and aimed at reducing socioeconomic disparity through engagement of local community, using the existing infrastructure to minimise the city's demolition costs (Rothman 2016). The non-profit RecoveryPark turned a blighted neighbourhood into massive urban farms by hiring ex-offenders, recovering addicts and others who faced barriers to employment (Sands 2013; Thibodeau 2015). Innovations in economic development were also taking shape, such as an institute that settled in

\footnotetext{
$\overline{6}$ Between 1973 and 2004, the City of Detroit came into possession of more than $15 \%$ of all properties (Dewar 2015).
} 
Detroit to use vacant industrial buildings for a new manufacturing centre for lightweight materials.

\section{Features and challenges of innovative strategic responses to decline in urban development politics}

The extensive philanthropic, non-profit, communitybased, grassroots, public and private sector efforts were mobilised in the frames of the DFC strategy to stop urban decline and realise an equitable, prosperous and sustainable Detroit of the future. The redevelopment strategy that advocated for the transformation of the urban crisis into a promising post-industrial experiment had to acknowledge that reviving Detroit's manufacturing base was unrealistic, and that the formerly prioritised physical upgrading of the built environment would not lure either jobs or residents back. However, the city administration in Detroit was in no position to admit that the industrial sector was economically unsustainable and "did not heed the wake-up call of declining population until it got to the point of bankruptcy" (Khan 2013). For this reason, declaration of municipal bankruptcy could be considered the most important response to Detroit's urban decline. On the one hand, bankruptcy showed that the power relations were forcing the city to abandon its path dependency and seek new development perspectives. On the other hand, it was also confirmation from the local officials and elites that decades of decline couldn't be reversed through simple implementation of any of the standard neoliberal policies. The need to adopt an innovative perspective for Detroit's future required a strategy based on stabilisation, recovery, and irreversible degrowth. This would be an admission of the grim reality that the city would not recover its industrial fame, something that Schindler (2016) termed 'degrowth machine politics'.

In contrast to similar cases of decline in Europe, an aggravating circumstance for the response in Detroit was an absence of the federal support to declining cities resulting from the lack of voting strength (Wolff 2013). This circumstance had direct implications for significant economic planning efforts from Detroit-based foundations and private institutions. Further, most of the investments in the downtown area were led by the forprofit private sector, which led to the types of revitalization that implied profound improvement of the physical structures. Sporadic investments in physical upgrading, however, were not enough to address social and economic issues, with segregation, social exclusion, and troubled neighbourhoods remaining serious problems. Finally, the lack of federal support and the bankruptcy of the city's administration could also be seen as an opportunity for more freedom in finding alternative ways for tackling the most burning issues of decline. Contrary to the EU experience, where the influence of politics from upper levels imposed political trends and planning fashions negotiated elsewhere to gear local urban governance (see Bernt 2009), the particular circumstances in Detroit actually provided production of innovative, inclusive and effective post-neoliberal local policy models.

Considering the rampant abandonment of properties, the DFC strategy made the most significant effects in reusing vacant lands and rightsizing, accomplished through neighbourhood and citywide greening strategies (Schilling and Logan 2008), and through the active involvement of many companies and non-profit organisations. However, this development priority faced some formidable implementation challenges. Municipal authorities had trouble finding investors willing to develop vast abandoned land and properties, one of the major limitations of urban entrepreneurialism in Detroit (see Schindler 2016). Local governments had to return vacant lands to productive reuse to bring more benefits for the neighbourhoods, and to ensure tax revenue. In addition to some people and non-profit organisations that purchased properties to redevelop, live in, or enlarge, a much larger group involved speculating investors ${ }^{7}$ who were interested in reselling or renting (Dewar 2015). Dewar's study of the reuse of abandoned property in Detroit and Flint confirmed that the sale of a property sometimes had less desirable side effects, like speculations, reselling, or absentee ownership (Dewar 2015), all of which also created a bad reputation for the institutions in charge. Dewar states, "the Detroit department kept a focus on making money from selling property and had a bad reputation for administration of sales (...)" (2015, p 360).

There was also a lack of mechanisms that could have prevented some unwanted phenomena. These included the inability of non-profit developers to outbid investors bidding on the sale of the vacant land, public authorities remaining responsible for the least usable properties, or even non-profit developers and homeowners who purchased many lots surrounding their homes, creating the 'new suburbanism' phenomenon (Armborst et al. 2008). The land bank and PDD finally failed to ensure support for this matter. As Dewar states, “(...) these organisations could likely do better in encouraging reuse of property after abandonment" (Dewar 2015, p 360).

Although the smart DFC strategic framework was revolutionary for Detroit in many ways, especially in its cooperation with community organisations, conflicts

\footnotetext{
${ }^{7}$ Hantz Farms bought 10,000 acres of land in downtown Detroit for the purpose of urban farming, getting under the public spotlight for purchasing prime real-estate land far below its market rate (Grimes 2016).
} 
among actors seemed to be inevitable, due to a clear difference in the priorities of local actors and extra-local investors. This disagreement created an array of challenges for successful implementation of the DFC policy. Given the magnitude of Detroit's social and racial segregation, some residents criticised the transparency of the programme, claiming that real intentions of the city officials were to evict residents from their homes and make the city more compact (Dolan 2011). In addition, in spite of developing partnership between the Kresge Foundation and the city government on relief and development work, the atmosphere of conflict between these key stakeholders raised further points of concern among the public. The Wall Street Journal reported that:

\section{The tug of war between Kresge [Foundation] and the Bing administration [Mayor Dave Bing and City Hall officials] raises serious questions for Detroit about whether City Hall and foundations can work as partners in saving the shrinking city from col- lapse. Caught in the struggle are tens of thousands of Detroiters waiting to find out whether their neigh- bourhoods will come alive with new investments, or be left to fade away (Dolan 2011).}

Many other issues fanned the flames of conflict among stakeholders in Detroit. The creation of new service industry jobs through culture-based strategies could not generate the same kind of workers and salaries that the industrial sector had (Story 2012). Disappointment in the response of the political system to urban fiscal problems and a lack of enthusiasm among investors resulted in some bizarre proposals, such as making Detroit's desperate economic and social conditions into a tourist attraction (Wolff 2013), or a zombie apocalypse theme park (Schindler 2016). Despite many efforts to control shrinkage in the short-term, the lack of clear steps that could have kept stakeholders united on their way to long-term prosperity only encouraged return of some questionable growth incentives, such Governor Snyder's call for federal action to 'embrace immigration' by offering 50,000 visas over the 5 years, making Michigan more hospitable to skilled immigrants (James 2014; McGraw 2015). This implies that innovation that came under the spotlight for redevelopment of Detroit failed to step out of the narrow approach to technological advancement and arrive at a broader understanding. Michigan Radio commented that

(i)nnovation is at the center of Detroit's inclusive recovery. Yet this word "innovation" is used so often that its meaning tends to get a little obscured (Kinkead 2015).

Similar to the results of the former initiatives, a progressive future for Detroit seemed to be slipping further away in the long-term development perspective. After embracing the bottom-up approach along with inevitable degrowth, effective implementation dynamics of the DFC strategy that revolutionary envisioned prosperity for Detroit in the foreseeable future was called into question soon after its inception in 2013.

\section{Conclusions}

Through the examination of a number of different initiatives and the official strategic framework to oppose urban decline in Detroit, this study has demonstrated the challenges that even highly elaborated urban development policies face at their implementation phase. This particularly relates to the policies that aim at breaking up with the dependence on industrial and commercial paths of development, and set up some new urban governance rationalities in the post-neoliberal societies.

In contrast to the opinion of some urban planners from the late twentieth century that Detroit could hardly ever be reconstructed (Eisinger 2003), the more recent optimistic viewpoint reminded that, in contrast to real death, city doesn't physically disappear, making revitalization of Detroit eventually a real possibility (Tabb 2015). Examples of former industrial cities of Chicago or Pittsburgh already demonstrated that death of industry didn't necessarily mean inability for a different city to evolve, although this surely depended not only on innovative strategies, but also on power relations in a city in question, political will and entrepreneurialism of the local government, and effective and collaborative framework for successful implementation. Although the DFC strategy in Detroit advocated for experimentation to avoid the harmful aspects of neoliberalism, probably the greatest impediment to its success was the lack of an equally innovative strategy to balance opposing interests. This is especially evident in the conflict between locally based actors on the one side, having an interest in the city's long-term future, and extra-local investors on the other, seeking short-term profit. In addition, although municipal bankruptcy and the lack of support from other levels of government allowed for the development of innovative strategic perspectives, they also contributed to the complex relationship between public and private institutions, especially when the public sector had significantly less influence.

The regeneration of cities and the development of new future development perspectives must be understood as an extremely complex, long-term process, in which innovation, flexibility, and collaborative efforts are of the highest importance. Following Oosterlynck and Gonzáles (2013), urban crises indeed hold the potential to reconsider and redefine neoliberal relationships, and approaching them in a creative and innovative way could lead to 
some progressive alternative models for urban governance. However, as this is a complex and hardly predictable task that is fraught with challenges, a collaborative and monitored long-term implementation strategy seems just as relevant as the innovative approach to crisis. This study has shown that post-neoliberal urban rationalities in time of crises should be understood as a broad and challenging topic that requires more scholarly attention.

\section{Authors' contributions}

The author read and approved the final manuscript.

\section{Authors' information}

Nebojša Čamprag is an urban planner and post-doctoral researcher based at the Faculty of Architecture (TU Darmstadt, Germany). His doctoral dissertation "Urban Identity and Change - a Comparison Between Frankfurt and Rotterdam", published in 2014, deals with the issues of identity and sense of place in contemporary cities, as a challenge that results from a range of global, economy-driven changes that cities are facing today. Nebojša's current research interest is in the framework of interaction between globalization and built environment on the level of international comparison, with the research foci on urban identity, effects of urban mega-projects, and issues of urbanity in the post-socialist cities.

\section{Acknowledgements}

The author would like to thank to the anonymous reviewers, as well as the editors, for very helpful and instructive comments on earlier versions of this article.

\section{Competing interests}

The author declares there is no competing interests.

\section{Availability of data and materials}

The dataset(s) supporting the conclusions of this article is(are) included within the article.

\section{Funding}

Not applicable.

\section{Publisher's Note}

Springer Nature remains neutral with regard to jurisdictional claims in published maps and institutional affiliations.

Received: 13 December 2017 Accepted: 30 April 2018 Published online: 23 May 2018

\section{References}

Alder S, Lagakos D, Ohanian L (2014) The decline of the US rust belt: a macroeconomic analysis. Micro 2013:1-44

Armborst T, D'Oca D, Theodore G (2008) Improve your lot! In: Rugare S, Schwarz T (eds) Cities growing smaller. Kent State University, Cleveland

Audirac I (2009) Urban shrinkage amid fast metropolitan growth (two faces of contemporary urbanism). In: Pallagst K et al (eds) The future of shrinking cities: problems, patterns and strategies of urban transformation in a global context. Center for Global Metropolitan Studies, Institute for Urban and Regional Development, and the Shrinking Cities International Research Network, Berkeley, pp 69-79

Badenhausen K (2013) Detroit tops 2013 list of America's most miserable cities America's most miserable cities. Forbes, pp 1-23. http://www.forbes.com

Beauregard RA (2007) Shrinking cities in the United States in historical perspective : a research note. The future of shrinking cities: problems, patterns and strategies of urban transformation in a global context, pp 61-68. http://metrostudies.berkeley.edu/pubs/proceedings/Shrinking/
Bentley GC, McCutcheon P, Cromley RG, Hanink DM (2016) Race, class, unemployment, and housing vacancies in Detroit: an empirical analysis. Urban Geogr 37(5):785-800. https://doi.org/10.1080/02723638.2015.1112642

Bernt M (2009) Partnerships for demolition: the governance of urban renewal in East Germany's shrinking cities. Int J Urban Reg Res 33(3):754-769. https://doi.org/10.1111/j.1468-2427.2009.00856.x

Bomey N, Woodyard C (2014) Detroit's savior promotes theme park honoring cars. Detroit Free Press and USA TODAY. https://www.usatoday.com/story /money/cars/2014/05/31/dan-gilbert-detroit/9804065/

Bontje M (2004) Facing the challenge of shrinking cities in East Germany: the case of Leipzig. GeoJournal. https://doi.org/10.1007/s10708-004-0843-7

Borney N, Gallagher J (2013) How Detroit went broke: the answers may surprise you- and don't blame Coleman Young. http://www.freep.com/artic le/20130915/NEWS01/130801004/Detroit-Bankruptcy-history-1950-debtpension-revenue

Brenner N, Theodore N (2002) Cities and the geographies of "actually existing neoliberalism". Antipode 34(3):349-379. https://doi. org/10.1111/1467-8330.00246

City of Detroit (2000) Detroit: a world class city III. City of Detroit, Detroit

City of Detroit (2012) Detroit future city-Detroit strategic Framework Plan. December 2012. Available online: https://kresge.org/sites/default/files/ Uploaded\%20Docs/Detroit-Future-Cityexecutive-summary.pdf

City of Detroit (2013) Detroit future city: 2012 Detroit strategic framework plan, 2nd printing. Detroit

City of Detroit (2014) Detroit future city: 2014 year end report. https://detro itfuturecity.com/wp-content/uploads/2014/02/DFC_2014YearEndRepo rt.pdf

Creswell J (2017) Quicken loans, the new mortgage machine. The New York Times. https://www.nytimes.com/2017/01/21/business/dealbook/quick en-loans-dan-gilbert-mortgage-lender.html

Detroit Free Press (2013) Editorial: Detroit Works offers a blueprint for taking charge of shrinking city. Www.freep.com/article/20130108/OPINI ON01/301090005/Editorial-A-blueprint-for-taking-charge-of-shrin king-city

Dewar M (2015) Reuse of abandoned property in detroit and flint: impacts of different types of sales. J Plan Educ Res 35(3):347-368. https://doi. org/10.1177/0739456X15589815

DFC Implementation Office (2017) Detroit future city. https://detroitfutureci ty.com/priorities/. Accessed 21 June 2017

Dickinson Blais M (2012) Creative vitality in Detroit

Dolan M (2011) Revival bid pits Detroit vs. donor. Wall Str J Online. p 21371. https://www.wsj.com/articles/SB100014240527023048879045763977603 19014524

Eisinger P (2003) Reimagining Detroit. City Commun 2(2):85-99. https://doi. org/10.1111/1540-6040.00042

Eisinger P (2014) Is detroit dead? J Urban Affairs 36(1):1-12. https://doi. org/10.1111/juaf.12071

Florcruz M (2013) China's newest real estate investment Craze: Detroit's housing crisis. http://www.ibtimes.com/chinas-newest-real-estate-investment -craze-detroits-housing-crisis-1360973. Accessed 221 April 2017

Gallagher J (2017) Dan Gilbert's impact on Detroit just keeps growing. Detroit Free Press. http://www.freep.com/story/money/business/columnists /2017/02/04/gilbert-detroit-quicken-duggan-quicken/97450578/

Grimes R (2016) New film "Land Grab" examines Detroit's controversial Hantz Farms. Michigan Radio. http://michiganradio.org/post/new-film-landgrab-examines-detroits-controversial-hantz-farms

Häußermann H, Siebel W (1988) Die schrumpfende stadt und die stadtsoziologie. In: Friedrichs J (ed) Soziologische stadtforschung. VS Verlag für Sozialwissenschaften, Wiesbaden, pp 78-94. https://doi.org/10.1007/9783-322-83617-5 5

Held S (2015) 10 Detroit urban farms rooting goodness into the city. Daily Detroit. http://www.dailydetroit.com/2015/07/06/10-detroit-urban-farms -rooting-goodness-into-the-city/

James F (2014) Michigan Governor: Immigrant Influx Could "JumpStart" Detroit. NPR. http://www.npr.org/sections/itsallpoli tics/2014/01/26/265741849/michigan-governor-immigrant-influx-could -jump-start-detroit

Katz B, Bradley J (2013) The metropolitan revolution-how cities and metros are fixing our broken politics and fragile economy. Brookings Institution Washington DC. https://doi.org/10.1080/09654313.2014.990607 
Khan S (2013) Detroit's bankruptcy: motor city's path to recovery. Harward Political Rev. http://harvardpolitics.com/united-states/detroits-bankr uptcy-motor-citys-path-recovery/

Kinkead BDAN (2015) With each new idea, momentum builds in Detroit. Michigan Radio. http://www.rooflines.org/4162/detroit_future_citys _plan_for_revitalization_pushes_job_creation/

Laitner B (2017) Peter Karmanos' bet on Pontiac's downtown is celebrated. Detroit Free Press. http://www.freep.com/story/news/local/michigan/ oakland/2017/03/27/peter-karmanos-brian-calley-pontiac-technology -industry-rap-aretha-big-sean-compuware-startups/99605004/

Liebmann H, Kuder T (2012) Pathways and strategies of urban regenerationdeindustrialized cities in eastern Germany. Eur Plan Stud 20(7):1155-1172. https://doi.org/10.1080/09654313.2012.674348

Logan JR, Molotch HL (1987) The city as growth machine. In: Urban fortunes. The Political Economy of Place, pp 50-98

Marshall C (2015) The renaissance center: Henry Ford II's grand design to revive Detroit-a history of cities in 50 buildings, day 42 . In: The Guardian. https ://www.theguardian.com/cities/2015/may/22/detroit-renaissance-cente r-henry-ford-ii-grand-design-history-cities-50-buildings-day-42

Martinez-Fernandez C, Audirac I, Fol S, Cunningham-Sabot E (2012) Shrinking cities: urban challenges of globalization. Int J Urban Regional Res 36(2):213-225. https://doi.org/10.1111/j.1468-2427.2011.01092.x

McGraw DJ (2015) The GOP immigration plan to save Detroit-and Syria. http://www.politico.com/magazine/story/2015/09/detroit-saved-by-syria n-immigrants-rick-snyder-immigration-gop-213206

McIntyre Hall L, Hall F (1993) Detroits urban regime: composition and consequence. Mid-Am Rev Sociol 17(2):19-37

Neill WJV (2015) Carry on shrinking?: the bankruptcy of urban policy in Detroit. Plan Pract Res 30(1):1-14. https://doi.org/10.1080/02697459.2014.997462

Oosterlynck S, González S (2013) “Don”t waste a crisis': opening up the city yet again for neoliberal experimentation. Int J Urban Regional Res 37(May):1075-1082. https://doi.org/10.1111/1468-2427.12064

Oosting J (2017) Group plans gerrymander fight in Michigan. http://www. detroitnews.com/story/news/politics/2017/02/24/redistricting-propo sal/98359316/. Accessed 21 April 2017

Oswalt P, Rieniets T (2006) Introduction. In Atlas of shrinking cities. Hatje Cantz Publishers, Ostfildern-Ruit

Owens R, Rossi-Hansberg E (2017) Rethinking Detroit, pp 1-46

Pallagst K (2009) Shrinking cities in the United States of America: three cases, three planning stories. In: Pallagst K, eds. The future of shrinking cities: problems, patterns and strategies of urban transformation in a global context. Center for Global Metropolitan Studies, Institute for Urban and Regional Development, and the Shrinking Cities International Research Network, Brighton, pp 81-88

Pallapst KM, Wiechmann T, Martinez-Fernández C (2011) Shrinking cities:international perspectives and policy implications. Routledge Adv Geogr. https://doi.org/10.4324/9780203597255
Reece J, Holley D (2013) Detroit at a crossroads: emerging from crisis and building prosperity for all. Wiley, Detroit

Rothman L (2016) Turning derelict buildings into an urban farm in Detroit. VICE Magazine. https://munchies.vice.com/en_us/article/turning-derel ict-buildings-into-an-urban-farm-in-detroit

Sands D (2013) RecoveryPark, Detroit Urban Agriculture Project, Would Create Jobs For Ex-Offenders, Addicts. In: Huffington Post. http://www.huffi ngtonpost.com/2013/06/03/recoverypark-detroit-urban-agricultur e-jobs_n_3379029.html

Schilling J, Logan J (2008) Greening the rust belt: a green infrastructure model for right sizing america's shrinking cities. J Am Plan Assoc 74(4):451-466. https://doi.org/10.1080/01944360802354956

Schindler S (2016) Detroit after bankruptcy: a case of degrowth machine politics. Urban Stud 53(4):818-836. https://doi.org/10.1177/0042098014 563485

Short JR (1996) The urban order - an introduction to cities, culture, and power. Blackwell, Oxford

Snyder M (2013) 25 facts about the fall of Detroit that will leave you shaking your head. http://theeconomiccollapseblog.com/archives/25-facts-about -the-fall-of-detroit-that-will-leave-you-shaking-your-head

Steinführer A, Bierzynski A, Großmann K, Haase A, Kabisch S, Klusácek P (2010) Population decline in polish and Czech cities during post-socialism? looking behind the official statistics. Urban Stud 47(11):2325-2346. https ://doi.org/10.1177/0042098009360224

Story L (2012) Michigan Town Woos Hollywood, but Ends Up With a Bit Part. The New York Times. 03. http://www.nytimes.com/2012/12/04/us/whenhollywood-comes-to-town.html?pagewanted=all\&_r=0\&pagewanted $=$ print

Tabb WK (2015) If Detroit is dead, some things need to be said at the funeral. J Urban Affairs 37(1):1-12. https://doi.org/10.1111/juaf.12173

The Huffington Post (2012) Detroit redistricting draft maps revealed by city council. http://www.huffingtonpost.com/2012/01/23/detroit-redistrict ing-draft-maps-city-council_n_1223170.html

The Kresge Foundation (2017) Offical Website. http://kresge.org/\#

The U.S. Census Bureau (2016) QuickFacts

Thibodeau I (2015) RecoveryPark project to revamp east side Detroit neighborhood with \$15 M plan. MLive Media Group. http://www.mlive.com/ business/detroit/index.ssf/2015/10/recovery_park_project_to_revam .html

Watson D, Moore A (2008) Housing crisis accelerates blight in Detroit neighborhoods. https://www.wsws.org/en/articles/2008/10/fore-o21.html. Accessed 21 April 2017

Wolff R (2013) How capitalism's great relocation pauperised America's "middle class"| Richard Wolff| Opinion|The Guardian.pdf. The Guardian, pp 15-18. https://www.theguardian.com/commentisfree/2013/jul/09/capitalism -relocation-pauperised-middle-class 